\title{
My Darling Hyeonhi's trip to Vietnam (945th to 960th of Tcheonzamun)
}

\author{
Hyeonhi Regina Park1, Kunjoo DaegonAndrea Kim², Jiah Anna Kim³, Rosa Kim², Alain Hamon5, Sohwa \\ Therese Kim ${ }^{6}$, Sangdeog Augustin $\mathrm{Kim}^{7 *}$ \\ ${ }^{1}$ Department of Elderly care and welfare, Joongbu University, Kumsan, Republic of Korea \\ 2Department of History, Yonsei University, Seoul, and Republic of Korea \\ ${ }^{3}$ Department d'Expertise economique, Universite de Paris-Est Creteil, Paris, France \\ ${ }^{4}$ Specialite d'Economie politique, Ecole des Hautes Etudes en Sciences Sociales(EHESS), Paris, France \\ ${ }^{5}$ Ecole Internationale Jean-Mermoz, Abidjan, Cote d'Ivoire \\ ${ }^{6}$ Department of French language and literature, Seoul Women's University, Seoul, Republic of Korea, \\ ${ }^{7}$ Department of Companion animal and animal resources science, Joongbu University, Kumsan, Republic of Korea
}

\section{*Corresponding Author}

Sangdeog Augustin Kim

\section{Article History}

Received: 23.08.2019

Accepted: 05.09.2019

Published: 30.12 .2019

\begin{abstract}
The present researchers tried to find this article about Tcheonzamun (The thousand character essay), and they used the 16 letters from 945th to 960th characters. "At last the Maeg wife would be happy", because her husband might make her to tell him from the smallest thing even up to the greatest thing in her mind. This is the theme of the third line (953rd-956th) of this poem. And this is the very thing which the Maeg wife desperately wanted to obtain from her husband. This is the conclusion of this poem of Tcheonzamun.
\end{abstract}

Keywords: "At last the Maeg wife would be happy", Tcheonzamun (The thousand character essay), the 16 letters from 945th to 960th characters, Korean pronunciation method for the translation, the interpret through the meaning of Chinese characters.

\section{LITERATURE REVIEW}

There are several reports about the translation of Tcheonzamun (The thousand character essay) into Korean language [1, 2]. Dallet[3] wrote that Tcheonzamun had been utilized as a text for children in Tsin(Qin, Ch'in) Empire. The Tsin(Qin, Ch'in) Empire was established in the era of BC 200. Until now the name of Maeg country was translated three times in Tcheonzamun. The first is interpreted as 'MaegEui ZaSik' (The children of Maeg country) [4] and the second is as 'Nae Maeg Am Soo' (My son and daughter of Maeg country) [5]. And the third is as 'MangGa ZeosSo' (We are thoroughly defeated!) [1], but the present researchers assumed that 'MaegA ZeosSo' (We are defeated! Oh my Maeg people!) is better interpreted. And this is the source of the researchers' belief that Tcheonzamun was written by Maeg people.

\section{Research Method And DATA}

The researchers used the book of Tcheonzamun (The thousand character essay) published in Republic of Korea [6], from 945th to 960th characters of the book. Two methods were utilized [2]; the first one is through Korean pronunciation of Chinese character, the other one through the meaning of Chinese character of this Tcheonzamun poem.

\section{The research question - the problematic}

It is thought for long time in Korea, Japan, China that Tcheonzamun (The thousand character essay) book was written by Chinese people. And why is it, Tcheonzamun, translated into Korean language [4, 2]? This fact suggests that the book of Tcheonzamun was written by the ancestor of Korean people.

Copyright @ 2019: This is an open-access article distributed under the terms of the Creative Commons Attribution license which permits unrestricted use, distribution, and reproduction in any medium for non commercial use (NonCommercial, or CC-BY-NC) provided the original author and source are credited. 


\section{Research Results And Discussions}

It is the translation of Tcheonzamun (The thousand character essay). At first it is the interpret on Korean language. This poem is consisted of 16 letters from 945th to 960th characters. And the meaning through Korean pronunciation of this poem is as follows;

\section{Order Korean Pronunciation of the Chinese characters Chinese character Transformed pronunciation in modern Korean language Its meaning}

945-948 연시매최(Yeon Si Mae Tchoi) 年矢每催 연신 미쳐(Yeonsin Mitcheo) 'Yeonsin' means gradually or often, 'Mitcheo' means insane. So this sentennce expressed that the Maeg wife became to be insane.

949-952 희휘랑요(Heui Hwi Lang Yo) 羲暉朗曜 휘휘 날아올라(Hwihwi Nalaola) 'Hwihwi' means the voice of wind or swiftly like wind, 'Nalaola' means to fly up. Therefore, this paragraph showed that the wife wanted to fly up to the heaven. In other words, she wanted to die.

953-956 선기현알(Seon Gi Hyeon Al) 旋璣懸斡 삼가 하느님으로(Samga Haneunimeuro) 'Samga' means carefully or politely, 'Haneunimeuro' means 'with the God' or 'to the LORD'. And this line signified that the Maeg wife was willing to come to the place of the LORD, the living God in the heaven.

The Maeg wife did not disappoint, because there is the last one to whom she was confident. This fact shows that Maeg people are not realistic race but idealistic one [7]. From this sentence, on the other while, it can be supposed that the Maeg wife would not make her life to the end even though the Maeg husband continued to treat her unkindly!..

957-960 회백환조 (Hoe Baeg Hwan Zo) 晦魄環照 허벅지게 하제(Heobeogzige Haze) 'Heobeogzige' means being fully satisfied. 'Haze' is a dialect of South Cheollado district and it shows the hope to do so with a expression of "Let me to do so!". And this sentence showed that the wife wanted to meet the living God in order to be in full joy in the presence of the LORD.

During the long time, as shown on 160 characters of ten poems (each poem is composed of 16 letters) of Tcheonzamun, the Maeg wife has tried to have good relation with her husband, but she felt that she failed. At that time there remained only one method; she wanted to rest on the existence of the LORD! She was going to search the peacefulness on the Lord instead of the love from her cold husband. On the other word, this sentence hints that the Maeg wife thought her husband as the Lord in her life.

I had a sorrow memory in my family.

One day my father Ilsoo Joseph Kim had tried to suicide himself. It was a happening when I was a pupil in the elementary school in the year of 1965 or 1966 . When I came to father and mother, my father was not in good humor while my mother was glad with my visit. The rainstorms caused floods in our house and our upland. Our house was half-broken and some of our upland was disappeared with the flood. At that time I lived with my grandfather and my grandmother. Sometimes when I missed my father and my mother, I went to Kwangju on foot to meet them. My father always loved me. I did not know the reason, but my father did not like me at that time nor my visit to him. Originally we had lived at Songjeong-eup, Kwangsan-gun, CheollaNam-do. But my father moved to Kwangju (now it is Kwangju Metropolitan city), it was because of disappointments on his agricultural work after the flood. There in Kwangju, my father and my mother became merchants with the work of buying and selling vegetables. One day of the period, my father wanted to kill himself in his room with a poisonous gas which was given off from the firing briquette. It took for me long time to understand the mind of my father at that time. It was when I became the father that I was able to understand a little my father. The true reason of separation of my family at the time, it was not my father but the flood. But did my father Ilsoo Joseph think that he was responsible for the separation of the family?

My father Ilsoo Joseph! Now your son Sangdeog Augustin, I am okay with the thinking about you and the remembrance of your undertaking and enduring the hard time of our family. I encouraged myself on my daily life with reminding you and your courage as a Father...

Now the researchers are going to translate this Tcheonzamun poem through the meaning of Chinese character. If the present second translation on Chinese characters will have the similar meaning to the first interpret -the previous one-, this second one supports the first interpret on Korean pronunciation. And this fact shows that the first interpret was well done. But there is a difference between the first interpret and the second translation. The interpret on Korean pronunciation is much stronger, while the translation on Chinese characters has a softer and more sophisticated meaning.

Augustin and Hyeonhi have the belief that the LORD keeps on helping them, and they continued to translate Tcheonzamun like this. 
Order Korean Pronunciation of the Chinese characters Chinese character. Its Translation

945-948 연시매최(Yeon Si Mae Tchoi) 年矢每 催 The present researchers deleted 'the person part (人)' from all of these four letters(年 矢 每 催), and the researchers advanced to translate the remained part of these four letters of (年-人=干) (矢人=大) (每-人=母) (催-人=山, [錐-金]).

I will prepare my shield (年-人=干) bigger and larger (矢-人=大) in order to make (催-人=山, [錐-金]) my wife (每-人=母 ) as a bird ([錐-金]) in a mountain (山). My God amen! I must make my shield (干) big (大). I am going to have a strong power and then nobody can attack me, and I can protect my wife, then my wife (母) will become free as a bird ([錐-金]) living in a mountain(山).

Yes, the ordinary man like Maeg husband with common sense can consider like this. And the Maeg husband or the ordinary man in the world thought that the rich, the power, the position is the most important thing in order to protect and to please his wife, the Maeg wife.

949-952 희휘랑요(Heui Hwi Lang Yo) 羲 暉 朗 曜. The present researchers deleted 'excellent (秀)' part from Heui (羲) letter and 'good (良)' part from Lang (朗) letter, because these parts of 'excellent (秀)' and 'good (良)' have the similar meaning. The researchers pulled out 'day (日)' part from both Hwi (暉) and Yo (曜) letters. And then, the researchers began to translate the remained part of these four letters of (羲-秀=羊, 戈) (暉-日=軍) (朗-良=月) (曜-日=羽, [錐-金]).

Our LORD! It is a mistake! It is not right! The Maeg husband thought that he was able to protect (羲-秀=羊, 戈) well the gentle sheep (羊) (here, the sheep means his wife) with the spear (戈) as soldiers would do (暉-日=軍). The Maeg husband had better (曜-日二羽, [錐-金]) prepare feathers (羽) beautiful and clear like the moon (月) for the bird ([錐-金]) (here, the bird means his wife).

The bird ([錐-金]), here the Maeg wife, would like to wear clear and comfortable (月) feathers (羽). In real meaning, it is the power (軍) for the bird, the Maeg wife. It was the very thing that kept safe (戈) the Maeg wife, the gentle woman like sheep(羊). JESUS of us, Augustin and Hyeonhi appreciate You amen! Thank you very much LORD of us, two people amen!

By the way, if thing which the Maeg wife had deeply wanted was not accomplished, what would she become? What would be the status of the Maeg wife? The fourth line (957th-960th) showed the appearance of the Maeg wife. So the researchers decided to translate the fourth line instead of third line (953rd-956th).

957-960 회백환조(Hoe Baeg Hwan Zo) 晦 魄 環 照. The present researchers subtracted 'the day(日)' parts from Hoe( 晦) and Zo(照). The meaning of 'the purely white (玉)' part and that of 'the white (白)' part are similar. And the researchers pulled out 'the clear and white (玉)' part from Hwan (環) letter and 'the white (白)' part from Baeg (魄) letter. Then, the researchers tried to translate the remained parts of the four letters of (晦-日=每) (魄-白=鬼) (環-玉=網，口，衣) (照-日=刀，口，火).

Our LORD amen! Such an unfavorable thing as the gloomy experience, or Satan, or the death of human-being (魄-白=鬼), on what condition does it often and always happen (晦-日=每)? The Maeg husband often said to his wife (照-日) about her speaking (口) in a negative method; he used to fire (火) the speaking of his wife and to cut (刀) the words of the Maeg wife. He often put the net (網) on her mouth (口) and said to her "Now your saying is not elegant. Please speak on a good manner (衣)!" If the Maeg husband stopped her wife to speak freely (環-王), people used often (每) to die (鬼). Amen my LORD!

The present researchers suggested that this poem of Tcheonzamun had been written for long time by a Maeg woman or number of Maeg women. What does it mean in the second line of this poem "The bird ([錐-金]), here the Maeg wife, would like to wear clear and comfortable (月) feathers (羽)"? The next third line of (953rd-956th) tells the truth.

953-956 선기현알(Seon Gi Hyeon Al) 璇 璣 懸 斡. The present researchers deleted 'a lot of (幾)' part from Gi(璣) character and 'several(縣)' part from Hyeon(懸) letter. Because both 'a lot of (幾)' and 'several (縣)' have similar signification. And the researchers omitted 'person (人)' parts from Seon(璇) and Al(斡) characters. Then, the researchers tried to translate the remained parts of the four characters of (璇-人=王 or 玉, 方, 疋) (璣-幾=王) (䀣-懸=心) (斡-人=十, 曰, 十, 斗).

If the husband, the king of the family(璣-幾=王), would want to work well and splendidly(王 or 玉) here and there(方) like a plant might develop its flower(㱜), he, the Maeg husband, should aid his wife to speak(日) to him, her husband, a lot of things(十) and again(十), and the Maeg wife would talk and talk again to her husband even up to the volume of large basket(斗) of her mind, and then she would feel relieved and refreshed(心). At this time he would be so. 
"At last the Maeg wife would be happy", because her husband might make her to tell him from the smallest thing even up to the greatest thing in her mind. This is the theme of the third line (953rd-956th) of this poem. And this is the very thing which the Maeg wife desperately wanted to obtain from her husband. This is the conclusion of this poem of Tcheonzamun.

Augustin wrote on the night of 26 March 2018 the next sentences with the title of 'My Darling Hyeonhi's trip to Vietnam'.

"Hyeonhi, you came back from the journey to Vietnam safely. And I am so happy that you returned from the trip to Vietnam during 22 March - 26 March 2018!"

\section{ACKNOWLEDGEMENTS}

We thank Mr Ilsoo Joseph Kim and Mrs Bohwa Kim, Mr Yeonghag Park and Mrs Hilye Sarah Kim, Ms Jieun Agatha Kim. We thank Father Jean Blanc. We thank Father Hifumi Iwazaki. We thank the students of Department of Companion Animal and Animal Resources Science in Joongbu University. We thank Mrs Tamako Hayashi and Mr Yoshihiro Hayashi, Mrs Francine Tenaillon and Professor Nicolas Tenaillon, Doctor Janghwan Oh, and the members of Daejeon Ludovicus of Ordo Franciscanus Saecularis(OFS).

\section{REFERENCES}

1. Park, H. R., \& Kim, S. A. (2017). Dont be an idiot! Fight! with the apparent title of you must write it in your words as historical records by your own hand: Translation of the poem on Tcheonzamun (the book of The Thousand Character Essay) from 673rd to 688th using Chinese characters and Korean pronunciation. Journal of Languages and Culture, 8(3), 24-27.

2. Hyeonhi, R. P., Jieun, A. K., Kunjoo, D. A., Jiah, A. K., Sohwa, T. K., Kim, R., ... \& Sangdeog, A. K. (2017). Ancient Koreans petition to God in Tcheonzamun: The thousand character essay poem (641st to 656th letters). Journal of Languages and Culture, 8(6), 79-84.

3. Dallet, C. H. (1874). Histoire de l'Eglise de Corée (History of Korean Catholic Church). Victor Palme. Paris. France, 11-99.

4. Park, H. R., Kim, J. A., Kim, K. D., Kim, J. A., Kim, S. T., Hamon, A., ... \& Kim, S. A. (2017). The son and the daughter of Maeg country, I am very proud of you! with a title I will do my best for my children as if I stood in front of God!:-Translation of the poem on Tcheonzamun (the book of The Thousand Character Essay), from 689th to 704th characters. Journal of Languages and Culture, 8(3), 28-31.

5. Kim, R., Kim, S. T., Kim, J. A., Kim, K. D. A., Kim, J. A., Park, H. R., ... \& Kim, S. A. (2017). You are magnifique, Maegs descendants!(769th-784th characters). Journal of Languages and Culture, 8(7), 85-90.

6. Kim, J. J. (2002). HanSeogBong Tcheonzamun.

7. Zhang, S.N.(2013). "Kangxizidian" Edited by Zhonghua Book Company in 2013, Beijing. 1716. 